\title{
Implementasi Forward Chaining Method Pada Sistem Pakar Untuk Deteksi Dini Penyakit Ikan
}

\author{
Linda Perdana Wanti ${ }^{*}$, Syahrur Romadlon² \\ ${ }^{1}$ Program Studi Teknik Informatika, Politeknik Negeri Cilacap \\ ${ }^{2}$ Program Studi Teknik Informatika, Universitas Amikom Purwokerto \\ ${ }^{1} J$ Jn. Dr. Soetomo No.1 Karangcengis Sidakaya, Kabupaten Cilacap, 53212, Indonesia \\ ${ }^{2}$ Jl. Letjend. Pol. Sumarto, Purwanegara Purwokerto Utara, Kabupaten Banyumas, 53127, Indonesia \\ E-mail: linda_perdana@ $@$ pnc.ac.id ${ }^{1}$, syahrurromadlon@gmail.com ${ }^{2}$
}

\section{Info Naskah:}

Naskah masuk: 11 Juni 2020

Direvisi: 3 Agustus 2020

Diterima: 8 Agustus 2020

\begin{abstract}
Abstrak
Penelitian ini bertujuan untuk membuat sebuah sistem cerdas berbasis komputer untuk deteksi dini penyakit ikan air tawar. Masalah yang sering dihadapi oleh pembudidaya ikan khususnya ikan air tawar adalah penyakit ikan yang diawali dengan tanda-tanda seperti luka-luka dipermukaan tubuh ikan, pendarahan pada insang, perut ikan yang tiba-tiba membesar dan berisi cairan, terlepasnya sirip pada ikan atau pada ekor ikan yang berakibat matinya ikan yang dibudidaya sehingga menurunkan produksi ikan air tawar. Sistem pakar yang dikembangkan mengimplementasikan metode forward chaining yang dimulai dengan penelusuran gejala-gejala yang dialami oleh ikan untuk menentukan tindakan preventif yang harus dilakukan dengan menginputkan gejala tersebut ke sistem. Pengembangan sistem pada penelitian ini menggunakan extreme programming (XP) dimana fleksibilitas metode ini mendukung semua perubahan yang terjadi pada saat pengembangan sistem pakar untuk mendeteksi penyakit ikan. Luaran dari penelitian yang dilakukan berupa sistem pakar yang memberikan informasi tentang penyakit ikan air tawar, penyebabnya dan cara menanggulanginya.
\end{abstract}

\section{Keywords:}

forward chaining;

fish disease;

freshwater fish;

expert system;

extreme programming

\section{Abstract}

This study aims to create a computer based intelligent system to detect freshwater fish disease. Problems often faced by fish farmers, especially freshwater fish, are fish diseases that begin with signs such us wounds on the surface of the fish's body, bleeding on the gills, fish's stomach which suddenly enlarges and is filled with fluid, the release of fins or the tail of the fish which results in the death of cultivated fish, thereby reducing freshwater fish production. The expert system developed to implement the forward chaining method which starts with tracking the symptoms experienced by fish to determine the preventive action that must be taken by bringing the symptoms to the system. System development in this study uses extreme programming (XP) where the flexibility of this method supports all changes that occur when developing an expert system to detect fish diseases. The output of the research carried out in the form of an expert system that provides information about freshwater fish diseases, the cause and how to overcome them.

\footnotetext{
*Penulis korespondensi: 


\section{Pendahuluan}

Ikan air tawar merupakan ikan yang sering dibudidayakan oleh para petani ikan karena mempunyai nilai ekonomis yang cukup tinggi. Himbauan pemerintah tentang gerakan memasyarakatkan makan ikan (Gemarikan) karena ikan mempunyai nilai protein hewani yang tinggi dan bagus untuk dikonsumsi juga menjadi salah satu pendukung ikan air tawar ini banyak dibudidayakan [1]. Beberapa varietas ikan air tawar yang sering dibudidayakan adalah ikan mujair, ikan mas, ikan lele, ikan gurame dan ikan patin. Menurut laporan KKP tahun 2019 jumlah konsumsi ikan sepanjang tahun 2019 mencapai 54,49 kilogram/kapita, jumlah ini menunjukkan peningkatan yang sangat signifikan jika dibandingkan dengan konsumsi ikan pada tahun 2011 yang hanya 31,5 kilogram/kapita [2]. Walaupun data tersebut merupakan gabungan dari jumlah keseluruhan konsumsi ikan dari segala sektor, tidak hanya ikan air tawar, tetapi tetap menjadi hal yang perlu diapresiasi karena kesadaran masyarakat akan Gemarikan mendapat respon yang baik. Hal ini menjadikan usaha budidaya ikan menjadi berkembang dan mengalami peningkatan dari mulai tahun 2011 sampai sekarang.

Beberapa permasalahan yang sering terjadi dan dihadapi oleh pembudidaya ikan khususnya ikan air tawar adalah banyak ikan mati dikarenakan oleh beberapa faktor yang sering menjadi penyebab ikan yang dibudidayakan mati adalah faktor cuaca, kualitas air dan penyakit ikan. Faktor cuaca yang tidak menentu dan seringkali tidak dapat diantisipasi. Cuaca ekstrim yang sering terjadi khusunya di Indonesia seperti curah hujan yang cukup tinggi yang sering datang bahkan pada musim yang seharusnya musim kemarau menjadi salah satu penyebabnya. Kualitas air yang harus diperhatikan tentang kebersihan maupun kelancaran sirkulasi air. Penurunan kualitas lingkungan yang menjadi penyebab banyak ikan yang dibudidayakan mati menjadi masalah yang masih harus dicari solusinya agar produksi ikan air tawar tetap mencukupi kebutuhan masyarakat.

Pembudidaya ikan air tawar mengidentifikasi gejalagejala yang terjadi pada ikan yang dibudidayakan mencari solusi atas permasalahan yang terjadi. Gejala-gejala tersebut yang nantinya dapat dikonsultasikan dengan pakar untuk mengetahui penyakit ikan yang menyerang ikan air tawar. Penyakit ikan yang timbul karena dampak dari faktor cuaca yang ekstrim dan kualitas air untuk budidaya dan penurunan kualitas lingkungan yang akan diselesaikan melalui penelitian ini dengan bantuan seorang pakar dengan pengetahuan dan pengalamannya yang ahli dalam bidang budidaya ikan terutama ikan air tawar yaitu dokter hewan atau penyuluh budidaya ikan air tawar.

Untuk mendapatkan data tentang penyakit yang seringkali menyerang ikan air tawar dan cara mengatasi penyakit tersebut diperoleh dengan berkonsultasi dengan pakar pada bidang ini seperti dokter hewan maupun penyuluh budidaya ikan khususnya ikan air tawar. Semua pengetahuan dari pakar nantinya akan ditransformasikan ke dalam sebuah sistem yang disebut sistem pakar yang dapat dimanfaatkan oleh pembudidaya ikan air tawar untuk mengetahui informasi terkait permasalahan yang terjadi pada ikan air tawar yang dibudidayakan.
Data penyakit ikan juga didapatkan dari pembudidaya ikan yang mengalami secara langsung gejala-gejala yang dialami ikan air tawar yang dibudidayakan. Sistem pakar yang dibangun merupakan representasi dari pengetahuan seorang pakar yang ahli dalam suatu bidang tertentu dan tidak terbatas ruang dan waktu artinya sistem pakar dapat digunakan kapan saja dan dimana saja [3].

Beberapa penelitian yang telah dilakukan sebelumnya antara lain adalah penelitian dari Febby yang membuat sebuah sistem informasi yang dapat menggantikan seorang pakar untuk mendeteksi penyakit demensia dengan mengimplementasikan alur penelusuran forward chaining, sistem yang dibuat digunakan untuk berkonsultasi layaknya seorang pasien dan dokter untuk mengetahui penyakit demensia dan tips-tips yang dapat digunakan untuk pencegahan penyakit tersebut dan berbasis website [4].

Penelitian selanjutnya oleh Rizal yang menjelaskan tentang sistem pakar untuk menganalisis gejala-gejala yang ditemui pada seorang anak. Gejala-gejala tersebut kemudian ditelusuri menggunakan forward chaining untuk mencari kesimpulan tentang adanya penyakit autis pada anak tersebut. Sistem pakar ini memberikan rekomendasi preventif untuk anak dengan penyakit autis. Biasanya untuk anak-anak yang Data anak yang diidentifikasi mengalami autis diambil dari SLB Cileunyi. Penelitian yang dilakukan oleh Rizal menghasilkan sebuah sistem berbasis komputer yang menginformasikan kemungkinan penyakit autis yang pada seorang anak sesuai dengan gejala yang dikonsultasikan terhadap sistem pakar ini [5].

Penelitian yang dilakukan oleh Bagus, dkk yang meneliti tentang deteksi dini penyakit pada anak dibawah lima tahun. Anak-anak yang diobservasi pada penelitian ini diawali dengan mengumulkan data-data gejala yang dialami, kemudian dilanjutkan dengan penelusuran berdasarkan hipotesa dan aturan-aturan yang ada dan berakhir pada sebuah kesimpulan. Tahapan tersebut mewakili forward chaining dimana penelusuran dimulai dengan mengamati gejala yang terjadi pada anak dan membawanya ke sebuah kesimpulan tentang penyakit yang diderita oleh anak dibawah lima tahun. Hasil penelitian membuktikan bahwa $82 \%$ tingkat keakuratan ini artinya dari 50 kasus yang diidentifkasi 41 kasus benar dan selebihnya salah [6].

Perbedaan penelitian ini dengan penelitian yang lainnya adalah pada penelitian ini masalah yang dihadapi adalah penyakit yang menyerang ikan air tawar yang dibudidayakan. Metode penelusuran yang digunakan dengan memilih gejala-gejala yang terjadi pada ikan yang dibudidayakan dan mengerucut ke sebuah kesimpulan dimana informasi mengenai penyakit yang menyerang ikan beserta dengan cara penangulangannya menjadi output dari sistem pakar ini atau lebih dikenal dengan penelusuran maju yaitu metode forward chaining. Sedangkan untuk mengembangkan sistem digunakan metode extreme programming yang lebih sesuai dan mudah diadaptasi dengan segala perubahan yang terjadi selama proses pembangunan sistem, dimana perubahan cenderung cepat dan sering terjadi. 


\section{Metode}

Sebuah sistem cerdas yang mampu menyerap informasi tentang sebuah kepakaran yang dapat dimanfaatkan untuk menyelesaikan sebuah permasalahan [7]. Pemanfaatan sistem pakar dapat digunakan dalam berbagai hal, seperti deteksi dini sebuah penyakit entah penyakit yang terjadi pada manusia, hewan maupun tumbuhan. Dengan menggunakan sistem pakar, seseorang yang awam terhadap sebuah permasalahanpun akan terbantu dan mengerti dengan masalah yang dihadapi [8]. Beberapa komponen utama yang mutlak ada di sistem pakar yaitu knowledge base, inference engine dan user interface. Basis pengetahuan merupakan sebuah komponen yang mutlak ada pada sebuah sistem pakar, karena tanpa basis pengetahuan, kepakaran tentang sebuah hal tidak dapat digunakan [9]. Basis pengetahuan berisi pengetahuan seorang pakar yang nantinya digunakan untuk mengurai permasalahan yang dihadapi dengan menerapkan dua hal yaitu fakta yang diidentifikasi dari gejala-gejala yang dialami dan aturan yang berisi tata cara perolehan informasi baru dari fakta yang telah terjadi sebelumnya [10]. Mesin inferensi digunakan pada saat proses penyesuaian faktafakta yang ada atau informasi gejala yang terjadi dengan aturan logika atau working memory yang telah diinputkan ke dalam aplikasi sistem pakar [11]. Komponen yang terakhir adalah user interface, atau antarmuka pengguna yang dapat digunakan user untuk mengakses pengetahuan pakar dan digunakan untuk menyelesaikan permasalahan yang terjadi [12]. User interface ini sebaiknya dibuat dengan memperhatikan kebutuhan user, maksudnya dibuat untuk memudahkan user dalam mengakses informasi pakar sehingga user akan mudah dalam berinteraksi dengan sistem pakar dan betah berlama-lama menggunakan sistem pakar yang dibangun [13].

Metode sitem pakar yang menerapkan konsep pencarian solusi atas sebuah permasalahan yang dimulai dengan penelusuran gejala-gejala yang dirasakan dan berakhir pada kesimpulan [14]. Forward chaining memulai penelusuran berdasarkan fakta-fakta yang terjadi kemudian menuju ke premis untuk ditarik kesimpulannya [15], atau banyak orang mengatakan metode forward chaining seperti model hierarki bottom up, penelusuran dari bawah menuju kepuncak kesimpulan.

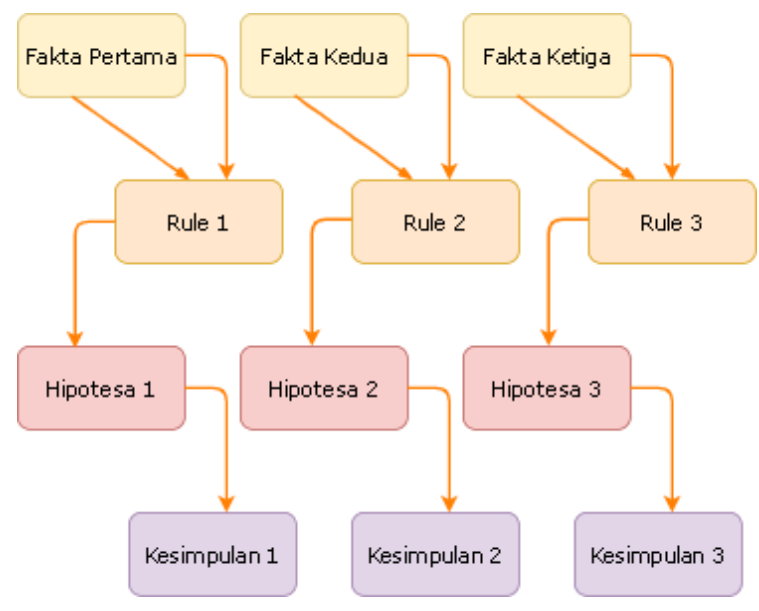

Gambar 1. Penelusuran Metode Forward Chaining
Untuk lebih memahami tentang konsep penelusuran menggunakan metode forward chaining dapat dijelaskan melalui Gambar 1. Pada gambar tersebut ditunjukkan alur penelusuran sebuah masalah menggunakan alur maju atau lebih dikenal dengan nama forward chaining model yang dimulai dari mendeskripsikan gejala yang dialami kemudian data gejala tersebut disesuaikan dengan rule yang telah diinputkan sebelumnya. Setelah sesuai dengan rule maka dilanjutkan ke hipotesa untuk memperoleh kesimpulan dari fakta yang ada tadi atau gejala yang dialami pada waktu sebelumnya [16].

Pengembangan sistem pakar untuk deteksi penyakit ikan air tawar menggunakan metode pengembangan sistem extreme programming (XP). Penggunaan metode XP sesuai dengan sistem pakar yang dikembangkan karena metode Xp dapat menyesuaikan dengan segala perubahan yang terjadi pada saat pengembangan sistem pakar ini [17]. Perubahan yang dimaksud dapat berasal dari kebutuhan user yang terus bertambah akan kesesuaian sistem dengan kemampuan user dalam beradaptasi dengan sistem pakar [18]. Perubahan tersebut nantinya akan disesuaikan dengan banyaknya iterasi yang terjadi pada proses pengembangan sistem pakar untuk deteksi penyakit yang menyerang ikan air tawar yang dibudidayakan. Perbaikan/perubahan pada saat proses pengembangan sistem pakar ini juga harus memperhatikan masukan dari end user yaitu pembudidaya ikan air tawar.



Gambar 2. Tahapan Extreme Programming

Tahapan pada metode XP seperti pada gambar 2 dimulai dengan identifikasi dan eksplorasi semua kebutuhan user yang menggunakan sistem pakar untuk deteksi penyakit ikan air tawar. dilanjutkan dengan membuat rencana kegiatan selama proses pengembangan sistem pakar ini. Kemudian memulai proses pembuatan sistem pakar sesuai dengan rencana iterasi dimulai dari iterasi pertama sampai dengan iterasi terakhir pengembangan sistem pakar selesai [19]. Iterasi yang terakhir sudah sesuai dengan semua kebutuhan yang diperlukan oleh user maka dimulai proses produksi sistem 
pakar, dan diakhiri dengan pemeliharaan sistem melalui recovery dan backup data secara berkala.

\section{Hasil dan Pembahasan}

\subsection{Identifikasi dan eksplorasi kebutuhan user sistem pakar}

Pada tahapan ini kebutuhan pengguna sistem pakar diidentifikasi dan dieksplorasi untuk mengetahui permasalahan yang dihadapi [20]. Masalah yang dihadapi pembudidaya ikan air tawar adalah penyakit ikan yang menyerang dan mengakitbatkan banyak ikan air tawar yang dibududaya menjadi mati sehingga proses produksi ikan mengalami penurunan dan pembudidaya ikan mengalami kerugian yang diawali dengan gejala-gejala yang dialami oleh ikan air tawar seperti luka-luka dipermukaan tubuh ikan, pendarahan pada insang, perut ikan yang tiba-tiba membesar dan berisi cairan, terlepasnya sirip pada ikan atau pada ekor ikan. Berangkat dari hal tersebut maka pembudidaya ikan memerlukan sebuah pakar untuk mengidentifikasi penyakit tersebut. Pakar yang dimaksud pada penelitian ini bisa dokter hewan ataupun penyuluh pembudidayaan ikan air tawar.

\subsection{Perencanaan kegiatan}

Perencanaan kegiatan meliputi jumlah iterasi yang direncanakan akan dilakukan. Jumlah ini disesuaikan dengan lamanya proses pengembangan sistem pakar yang berkoordinasi dengan kebutuhan pengguna akhir dari sistem pakar ini [21]. Data penyakit dan data gejala yang dialami oleh para pembudidaya ikan air tawar sebagai basis pengetahuan sistem pakar diidentifikasi pada tahap ini. Kemudian data tersebut digunakan pada proses selanjutnya untuk membuat mesin inferensi sistem pakar. Data tentang penyakit ikan dijelaskan pada Tabel 1 .

Tabel 1. Jenis Penyakit Ikan Air Tawar

\begin{tabular}{|c|c|c|}
\hline No & $\begin{array}{c}\text { Kode } \\
\text { Penyakit Ikan }\end{array}$ & Nama Penyakit Ikan \\
\hline 1 & P01 & $\begin{array}{l}\text { Epizootic Ulcerative Syndrome (EUS) } \\
\text { / Myotic Granulomatosis (MG) / Red } \\
\text { Spot Disease (RSD) }\end{array}$ \\
\hline 2 & $\mathrm{P} 02$ & Saprolegniasis \\
\hline 3 & $\mathrm{P} 03$ & Branchiomycosis \\
\hline 4 & P04 & $\begin{array}{l}\text { Bintik Putih (White-spot) atau Ich } \\
\text { (ichthyophthiriasis). }\end{array}$ \\
\hline 5 & P05 & Trichodiniasis (Penyakit Gatal) \\
\hline 6 & P06 & Myxosporidiasis (Penyakit Gembil) \\
\hline 7 & P07 & Dactylogyriasis (Cacing Insang) \\
\hline 8 & P08 & Gyrodactyliasis (Cacing Kulit) \\
\hline 9 & P09 & Lerniasis \\
\hline 10 & P10 & Argulosis \\
\hline 11 & P11 & Isopodiasis \\
\hline 12 & P12 & $\begin{array}{l}\text { Penyakit Merah (Motile Aeromonas } \\
\text { Septicemia) }\end{array}$ \\
\hline 13 & P13 & Columnaris Disease \\
\hline 14 & P14 & Penyakit Streptococciasis \\
\hline 15 & P15 & $\begin{array}{l}\text { Penyakit Mycobacteriosis / Fish } \\
\text { Tuberculosis (TB) }\end{array}$ \\
\hline 16 & P16 & Bacterial Finltail RotlPseudomoniasis \\
\hline 17 & P17 & Edwarsiellosis \\
\hline 18 & P18 & Enteric Septicemia of Catfish (ESC) \\
\hline
\end{tabular}

Data penelitian tentang penyakit ikan, gejala, peyebab dan solusi diperoleh dari pakar dan hasil observasi dengan pembudidaya ikan yang diintegrasikan untuk menyamakan ke dua sumber data tersebut antara data dari pakar yaitu seorang dokter hewa atau penyuluh budidaya ikan air tawar dan yang terjadi sebenarnya di lapangan.

\subsection{Pembangunan sistem}

Pembangunan sistem dimulai dengan membuat mesin inferensi yang digunakan pada sistem pakar untuk deteksi penyakit ikan ini. Dimulai dengan merelasikan data penyakit dan data gelaja sebagai aturan yang digunakan pada proses penelusuran menggunakan metode forward chaining yang ditunjukkan Tabel 2.

\begin{tabular}{cll}
\begin{tabular}{c} 
Tabel 2. Kode Gejala Penyakit dan Kode Penyakit Ikan Air Tawar \\
\cline { 2 - 3 } No
\end{tabular} & \multicolumn{1}{c}{ IF } & THEN \\
\hline 1 & GP01, GP02, GP03 & P01 \\
2 & GP04, GP05 & P02 \\
3 & GP06, GP07, GP08 & P03 \\
4 & GP09, GP10, GP11, GP12 & P04 \\
5 & GP10, GP13, GP14, GP15, GP16, GP17 & P05 \\
6 & GP18, GP19, GP20, GP21 & P06 \\
7 & GP09, GP13, GP14, GP22, GP23 & P07 \\
8 & GP10, GP24, GP25 & P08 \\
9 & GP26, GP27 & P09 \\
10 & GP10, GP28, GP29, GP30 & P10 \\
\hline
\end{tabular}

Pada Tabel 2 dijelaskan bahwa kode GP01 sampai dengan GP30 menunjukkan data gejala yang ditemukan pada ikan yang mati oleh pembudidaya ikan air tawar, sedangkan data P01 sampai dengan 10 mewakili data penyakit yang menjangkiti ikan dan data penyakit ikan tersebut diperolah dari pakar. Data tersebut kemudian dibuat rulenya untuk selanjutnya digunakan pada tahap produksi sistem pakar sebagai mesin inferensi sistem pakar yang dibangun.

\subsection{Iterasi sistem}

Tahapan iterasi dimulai dengan iterasi pertama meliputi pembuatan antar muka sistem pakar yang kemudian diberikan kepada user untuk mendapatkan feedback dari user, apakah sudah sesuai dengan kebutuhan user atau adayang perlu ditambah [22]. Hasil dari feedback ini kemudian digunakan untuk membuat iterasi yang kedua dan selanjutnya seperti itu.

Pada tahap ini dibuat activity diagram untuk proses konsultasi dari sisi user sebagai pemakai sistem, diagram activity tersebut dijelaskan pada Gambar 3. Pada gambar tersebut user memulai kegiatan konsultasi dengan memilih menu konsultasi pada sistem pakar kemudian sistem akan menampilkan halaman konsultasi. User memilih gejala yang dialami oleh ikan yang dibudidaya kemudian sistem akan merespon dengan menampilkan penyakit pada ikan air tawar berdasarkan gejala yang dipilih oleh user. 


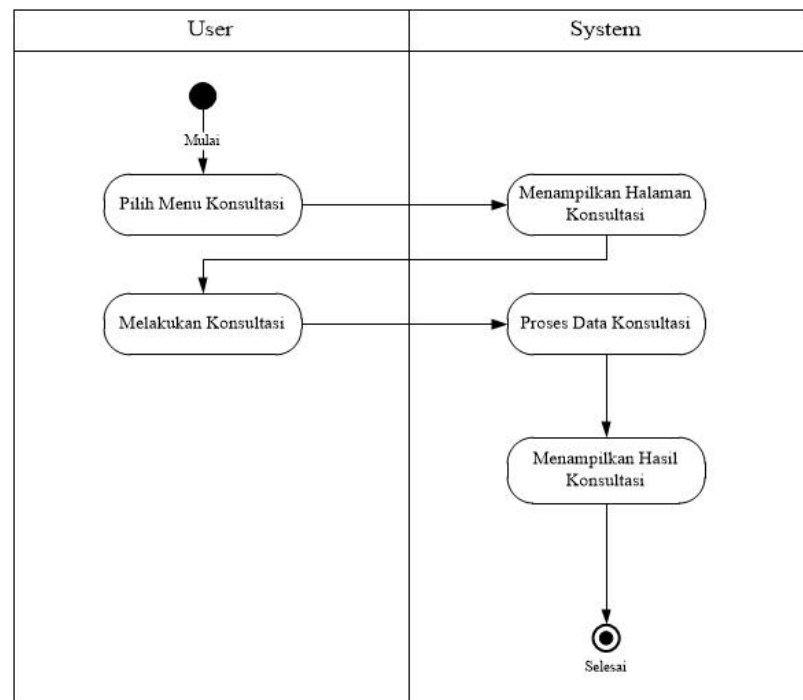

Gambar 3. Activity Diagram Proses Konsultasi

\subsection{Iterasi Terakhir Pembangunan Sistem}

Hasil dari tahapan iterasi yang telah dilalui kemudian digunakan oleh sistem sebagai hasil yang paling baik untuk dilanjutkan pada proses produksi sistem [23]. Semua kebutuhan user sudah terekap dengan baik melalui feedback yang diberikan pada tahapan iterasi sebelumnya. Rancangan user interface sistem pakar pada tahapan ini dianggap sudah final karena sudah melalui beberapa iterasi yang setiap iterasi dikonsultasikan dengan end user. Rancangan user interface yang sudah pada tahap akhir akan dibuat implementasinya sesuai dengan modul-modul sistem pakar yang telah disepakati sebelumnya dengan pengguna akhir.
Salah satu rancangan user interface yang sudah sampai pada tahap iterasi terakhir yaitu halaman daftar untuk pengguna sistem yang akan mengakses sistem pakar untuk deteksi dini penyakit ikan air tawar. pada halaman tersebut user diminta untuk memasukkan data yang berisi nama, alamat, username dan password. Nantinya data tersebut akan disimpan pada database sistem, sehingga ketika user akan mengakses kembali sistem pakar cukup memasukkan username dan password saja. Rancangan user interface halaman daftar ditunjukkan pada Gambar 4.

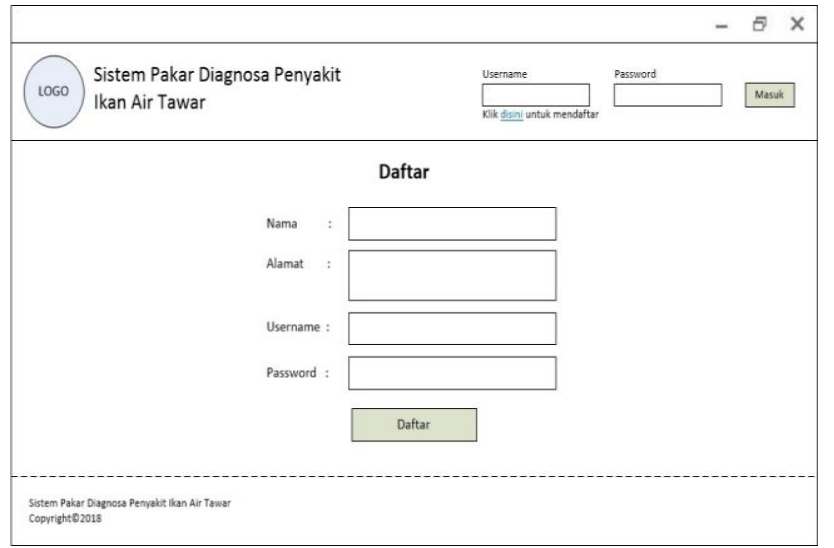

Gambar 4. Rancangan User Interface Halaman Daftar

\subsection{Tahapan Produksi Sistem}

Tahap produksi sistem dimulai dengan membuat coding sistem pakar yang sesuai dengan aturan/ rule menggunakan penelusuran maju yang digambarkan pada Gambar 5.

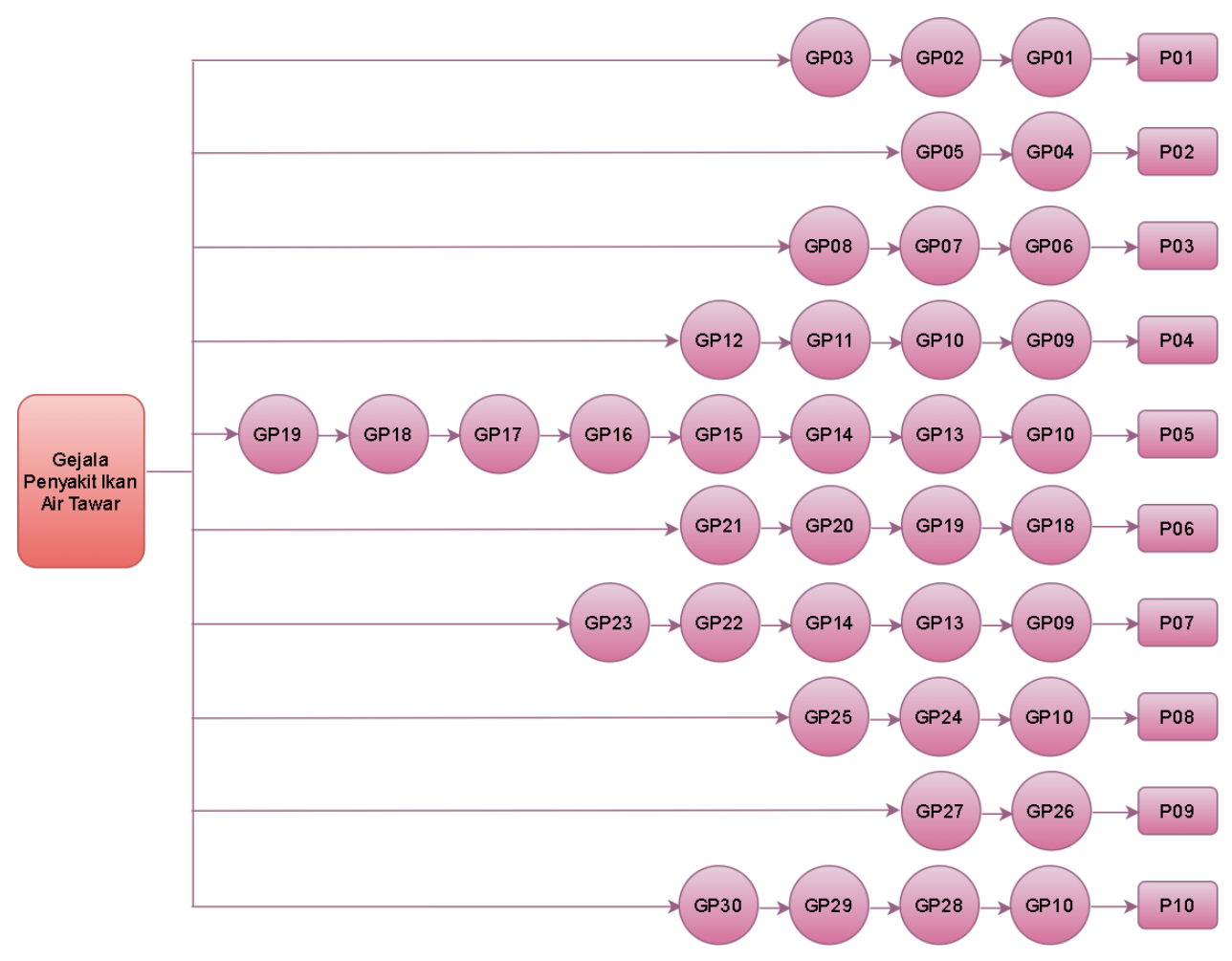

Gambar 5. Alur Penelusuran Sistem Pakar Deteksi Penyakit Ikan Air Tawar 
Pada Gambar 5, menjelaskan tentang penelusuran menggunakan metode forward chaining. Penelusuran dimulai dengan menampung semua data gejala yang dialami oleh ikan air tawar untuk sampai ke pada kesimpulan akhir. Data gejala yang diidentifikasi dengan kode GP01 sampai dengan GP30 dikelompokkan berdasarkan penyakit yang dapat menyerang ikan air tawar.kode penyakit diidentifikasi dengan kode P01 sampai dengan P10. Kesimpulan akhir dari proses penelusuran ini dinyatakan dengan kode penyakit yang sesuai dengan gejala yang dialami. Pada tahapan ini semua desain dari tahapan sebelumnya diproduksi atau diproses menjadi satu dan menghasilkan sistem pakar untuk mendeteksi penyakit ikan air tawar.

\subsection{Pemeliharaan sistem}

Tahap pemeliharaan sistem merupakan tahapan akhir dari metode pengembangan sistem extreme programming. Tahap ini terbagi menjadi dua kegiatan yaitu recovery sistem yang dilakukan apabila terdapat error yang muncul pada saat sistem dijalankan setelah dipakai oleh end user dan backup database dilakukan untuk mengamankan data secara berkala sesuai dengan kebutuhan dari end user, bisa setiap 6 bulan atau setiap 12 bulan tergantung kesepakatan yang telah dilakukan sebelumnya pada tahap perencanaan

\section{Kesimpulan}

Telah berhasil dibuat sebuah sistem pakar yang dapat dimanfaatkan untuk mendeteksi penyakit yang menjangkiti ikan air tawar dengan menggunakan alur penelusuran berdasarkan gejala yang dialami oleh ikan air tawar dan menggunakan metode pengembangan sistem extreme programming. Sistem pakar ini dapat digunakan untuk berkonsultasi menyelesaikan masalah selayaknya berkonsultasi dengan pakar [24]. Pembudidaya ikan air tawar mendapatkan informasi dan cara penanganan penyakit yang menyerang ikan yang dibudidayakan. modulmodul yang adapada sistem pakar dapat dioptimalkan untuk mencari informasi seputar penyakit ikan.

\section{Daftar Pustaka}

[1] R. Indonesia, Peraturan Menteri Kelautan Dan Perikanan Republik Indonesia. 2017.

[2] T. P. KKP, “Laporan Kinerja KKP Tahun 2019,” 2019.

[3] R. Rada, "Expert systems and evolutionary computing for financial investing: A review," Expert Syst. Appl., vol. 34, no. 4, pp. 2232-2240, 2008.

[4] F. Kesumaningtyas, "Sistem Pakar Diagnosa Penyakit Demensia Menggunakan Metode Forward Chaining Studi Kasus (Di Rumah Sakit Umum Daerah Padang Panjang)," J. Edik Inform. Penelit. Bid. Komput. Sains dan Pendidik. Inform., vol. 3, no. 2, pp. 95-102, 2017.

[5] R. Rachman, "Penerapan Sistem Pakar Untuk Diagnosa Autis Dengan Metode Forward Chaining," J. Inform., vol. 6, no. 2, pp. 218-225, 2019.

[6] B. F. Yanto, I. Werdiningsih, and E. Purwanti, "Aplikasi Sistem Pakar Diagnosa Penyakit Pada Anak Bawah Lima Tahun Menggunakan Metode Forward Chaining," J. Inf. Syst. Eng. Bus. Intell., vol. 3, no. 1, p. 61, 2017.

[7] F. Dweiri, S. Kumar, S. Ahmed, and V. Jain, "Corrigendum to ' Designing an integrate $\mathrm{d}$ AHP base d decision support system for supplier selection in automotive industry ' Expert Systems," Expert Syst. Appl., vol. 72, pp. 467-468, 2017.

[8] L. P. Wanti, I. N. Azroha, and M. N. Faiz, "Implementasi User Centered Design Pada Sistem Pakar Diagnosis Gangguan Perkembangan Motorik Kasar Pada Anak Usia Dini," Media Apl., vol. 11, no. 1, pp. 1-10, 2019.

[9] M. Castelli, L. Manzoni, L. Vanneschi, and A. Popovič, "An expert system for extracting knowledge from customers' reviews: The case of Amazon.com, Inc.," Expert Syst. Appl., vol. 84, pp. 117-126, 2017.

[10] S. Dai et al., "SeDeM expert system for directly compressed tablet formulation: A review and new perspectives," Powder Technol., vol. 342, pp. 517-527, 2019.

[11] J. Zhang, E. L. Prater, and I. Lipkin, "Feedback reviews and bidding in online auctions: An integrated hedonic regression and fuzzy logic expert system approach," Decis. Support Syst., vol. 55, no. 4, pp. 894-902, 2013.

[12] E. Susilo, F. D. Wijaya, and R. Hartanto, "Perancangan dan Evaluasi User Interface Aplikasi Smart Grid Berbasis Mobile Application," J. Nas. Tek. Elektro dan Teknol. Inf., vol. 7, no. 2, pp. 150-157, 2018.

[13] L. Perdanawanti and S. Setiajid, "Aplikasi Kamus Dasar Bahasa Jepang Berbasis Android Menggunakan Metode User Centered Design," Telematika, vol. 10, no. 2, pp. 7791, 2017.

[14] J. A. Putra, A. M. Galwargan, and N. O. Adiwijaya, "Decision support system scheme using forward chaining and simple multi attribute rating technique for best quality cocoa beans selection," Int. Conf. Electr. Eng. Comput. Sci. Informatics, vol. 2018-Octob, pp. 122-127, 2018.

[15] A. Pramana gusman, "Sistem Pakar Diagnosa Autis Pada Anak Dengan Menggunakan Metode Forward Chaining," vol. 9, no. 1, pp. 1-8, 2017.

[16] S. H. Liao, "Expert system methodologies and applicationsa decade review from 1995 to 2004," Expert Syst. Appl., vol. 28, no. 1, pp. 93-103, 2005.

[17] R. Rahmi, R. Sari, and R. Suhatman, "Pendekatan Metodologi Extreme Programming pada Aplikasi ECommerce (Studi Kasus Sistem Informasi Penjualan Alatalat Telekomunikasi)," J. Komput. Terap., vol. 2, no. 2, pp. 83-92, 2016.

[18] R. Fojtik, "Extreme programming in development of specific software," Procedia Comput. Sci., vol. 3, pp. 14641468, 2011.

[19] R. A. Azdy and A. Rini, "Penerapan Extreme Programming dalam Membangun Aplikasi Pengaduan Layanan Pelanggan (PaLaPa) pada Perguruan Tinggi," J. Teknol. Inf. dan Ilmu Komput., vol. 5, no. 2, p. 197, 2018.

[20] T. Gumelar, R. Astuti, and A. T. Sunarni, "Sistem Penjualan Online Dengan Metode Extreme Programming," J. Telemat., vol. 9, no. 2, pp. 87-90, 2017.

[21] J. G. Schneider and L. Johnston, "eXtreme Programming Helpful or harmful in educating undergraduates?," J. Syst. Softw., vol. 74, no. 2 SPEC. ISS., pp. 121-132, 2005.

[22] A. Supriyatna, "Metode Extreme Programming Pada Pembangunan Web Aplikasi Seleksi Peserta Pelatihan Kerja,” J. Tek. Inform., vol. 11, no. 1, pp. 1-18, 2018.

[23] D. H. Pertiwi, "Metode extreme programming (xp) pada website sistem informasi franchise lkp palcomtech," $J$. Mikrotik, vol. 8, no. 1, pp. 86-98, 2018.

[24] K. B. Ooi and G. W. H. Tan, "Mobile technology acceptance model: An investigation using mobile users to explore smartphone credit card," Expert Syst. Appl., vol. 59, pp. 33-46, 2016. 